\title{
Assessment of production potential of long-linted Gossypium arboreum L. genotypes under different sowing times
}

\author{
K. Sankaranarayanan ${ }^{{ }^{*}}$, M. V. Venugopalan ${ }^{2}$ and D. Kanjana ${ }^{1}$
}

\begin{abstract}
Background: Gossypium arboreum is one of the cultivated diploids which has inherent resistance against insect pests and diseases, can withstand moisture stress, needs less nutrients and is suitable for erratic, less rainfall and marginal soils. Due to its smaller boll size and poor locule retentivity, adoption of species by farmers is very low. So, best longlinted G. arboreum genotypes with high yielding potential and suitable sowing time will be identified for rainfed tracts of cotton cultivated areas in India.

Results: The pooled analysis results found that the significantly highest mean seed cotton yield was recorded with Phule Dhanwanthry (1069 kg/ha) which was on par with K12 (1027 kg/ha), DLSA 17 (977 kg/ha) and PA 812 (951 kg/ ha). Planting at 4 August yielded the significantly higher seed cotton yield (1345 kg/ha) in comparison with 4 September sowing $(536 \mathrm{~kg} / \mathrm{ha})$. The interaction results in pooled data revealed that Genotype PA 812 planted at 4 August registered the significantly highest seed cotton yield (1487 kg/ha) which was on par with all genotypes sown on 4 August except PA 402. Amongst long-linted genotypes, PA 760 recorded the significantly highest upper half length (29.9 mm), mean length $(24.9 \mathrm{~mm})$ and fibre strength (27.0 g/tex) and fibre quality index (349.7); which was on par with DLSA 17, PA 812 and PA 402. The quality characters had not been influenced significantly by different times of sowing.

Conclusions: The results concluded that the significantly highest mean seed cotton yield was recorded with Phule Dhanwanthry (1069 kg/ha) which was on par with K12 (1027 kg/ha), DLSA 17 (977 kg/ha) and PA 812 (951 kg/ha). Planting at 4 August found that the significantly higher seed cotton yield (1345 kg/ha) in comparison with 4 September sowing (536 kg/ha). Amongst long-linted genotypes, PA 760 recorded the significantly higher fibre quality index (349.7)
\end{abstract}

Keywords: Cotton genotypes, Times of sowing, Long-linted G. arboreum, Seed cotton yield

\section{Background}

Cotton is one of the most important cash crops of India. Among the four cultivated species of cotton, today, Gossypium arboreum L. (G. arboreum) is grown to a limited extent in Africa and Asia. In tropical Africa, Gossypium arboreum is grown for domestic use only (Brink 2011).

\footnotetext{
*Correspondence: sankaragro@gmail.com

${ }^{1}$ ICAR-Central Institute for Cotton Research, Regional Station,

Coimbatore, Tamil Nadu 641003, India

Full list of author information is available at the end of the article
}

The area under G. arboreum in India reduced from $65 \%$ of the total cotton area in 1947 to $17 \%$ in 2000 to around $3 \%$ a decade after the introduction of Bt hybrids (Blaise et al. 2020; Kranti 2015; Narayanan et al. 2014). Gossypium arboreum has the ability to provide resistance against insect pests and diseases, can withstand moisture stress, needs less nutrients and is suitable for erratic, less rainfall and marginal soils (Sankaranarayanan et al. 2010; Iqbal et al. 2019). Despite these advantages, this species is not currently preferred by farmers due to their small boll size and poor locule retentivity (Venugopalan et al.2016). 
The efforts were made for development of high yielding G. arboreum genotypes with high-quality lint by interspecific hybridization (Manivannan et al. 2018). Recently released G. arboreum genotypes have industrially acceptable fibre properties with high yield potential. These improved long G. arboreum may be suitable for rainfed tracts of India where production by current Bt hybrids has reached a plateau. One of the most significant agronomic considerations for growers to maximize yield is to select a suitable sowing time. In the present investigation, new genotypes of long-linted $G$. arboreum have been evaluated to assess the performance on yield, and fibre quality traits as well as to identify the best genotype and sowing time for rainfed conditions in Coimbatore tract.

\section{Methods}

\section{Experimental site}

Studies were conducted during growing seasons 2017/18, 2018/19 and 2019/20 at ICAR- Central Institute for Cotton Research, Coimbatore ( $\mathrm{N} 11^{\circ}, \mathrm{E} 77^{\circ}$ with an altitude of $427.6 \mathrm{~m}$ above MSL) Tamil Nadu, India. The region has a subtropical climate with annual rainfall of $657 \mathrm{~mm}$ (70 years average). The soil was clay loam in texture, low in available $\mathrm{N}(180.3 \mathrm{~kg} / \mathrm{ha})$, medium in available $\mathrm{P}$ $(17.5 \mathrm{~kg} / \mathrm{ha})$ and high in available $\mathrm{K}(812 \mathrm{~kg} / \mathrm{ha})$ with a $\mathrm{pH}$ 8.6 and EC $0.23 \mathrm{dS} / \mathrm{m}$. Soil test on micronutrient showed $0.48,1.2,3.62,2.64$ and 0.06 ppm of DTPA-extractable zinc, copper, manganese, iron and boron (hot water extract), respectively. The rainfall received during cropping periods reported in Table 1.

\section{Experimental design and field management}

Six long-linted G. arboreum genotypes viz., G1.DLSA17, G2.PA760, G3.PA812, G4.PA402, G5.PA528 and G6.K12 were planted at two different times of sowing (4 August and 4 September) with high density $(60 \times 10 \mathrm{~cm})$. These genotypes were compared with a short-stapled genotype G7.P.Dhanwanthry $(60 \times 10 \mathrm{~cm})$. The experiment was

Table 1 Monthly Rainfall (mm) of experimental years (2017, 2018 \& 2019)

\begin{tabular}{lcll}
\hline Standard months & \multicolumn{3}{c}{ Rainfall $(\mathbf{m m})$} \\
\cline { 2 - 4 } & $\mathbf{2 0 1 7}$ & $\mathbf{2 0 1 8}$ & $\mathbf{2 0 1 9}$ \\
\hline August & 38.5 & 58.4 & 223.9 \\
September & 218.1 & 2 & 54.7 \\
October & 132.6 & 178.2 & 227.5 \\
November & 78.1 & 30.5 & 202.1 \\
December & 1.2 & 12 & 21 \\
January* & 2.2 & 0 & 0 \\
\hline
\end{tabular}

* Succeeding year designed in a factorial randomized complete block design with three replicates. The recommended level of nutrients for G. arboreum 20:0:0 kg/ha of $\mathrm{N}, \mathrm{P}_{2} \mathrm{O}_{5} \& \mathrm{~K}_{2} \mathrm{O} / \mathrm{ha}$ was followed uniformly. The crop was raised by providing pre-sowing irrigation and then treated as rainfed crop. Weed control practices included pre-plant incorporated pendimethalin $1.25 \mathrm{~kg}$ ai/ha (stomp extra) and hand hoeing to maintain weed-free plots. The net plot size of $26.8 \mathrm{~m}^{2}$ was followed for experimentation.

\section{Data collection and analysis}

Randomly selected plants (five) were used for biometric observations that include growth characters and yield attributes. Seed cotton yield was obtained from each net plot. Plot wise seed cotton was ginned to determine fibre quality parameters. Fibre quality parameters were estimated by using HVI (Statex-Fibrotex). Fibre quality index, $\mathrm{FQI}=\mathrm{LT} / \sqrt{ } \mathrm{M}$, where $\mathrm{L}$, upper half length $(\mathrm{mm})$, $\mathrm{T}$, fibre bundle tenacity at $3.2 \mathrm{~mm}$ micron (g/tex) and $M$, micronaire value $(\mu /$ inch) were estimated. Nutrient uptake was also estimated. A combined analysis of variance was performed to determine the effect of genotype (G), different sowing dates (T) and $\mathrm{G} \times \mathrm{T}$ interaction on studied traits from three trials in three years. All data were subjected to analysis of variance at $P<0.05$. To estimate the significance between means, the standard error of difference and critical difference were used. Correlation studies have been carried out in G. arboreum genotypes between quantitative characteristics. Combined analysis of variance, correlation coefficients ( $r$ ) and their significance have been determined according to Snedecor and Cochran (1980).

\section{Results}

\section{Growth characters}

Amongst genotypes tested in the trial, the mean tallest plant observed with $\mathrm{K} 12(119.0 \mathrm{~cm})$ in the year $2017-18$ and with PA $402(125.8$ and $150.1 \mathrm{~cm})$ in the years of 2018-19 and 2019-20, respectively (Table 2). The shortest plant observed with Phule Dhanwanthry of 91.0, 100.5 and $120.4 \mathrm{~cm}$ in the years of 2017-18, 2018-19 and 2019-20, respectively. The result on height to node ratio $(\mathrm{H} / \mathrm{N})$ revealed that Phule Dhanwanthry registered significantly shortest in the years of 2018-19 (4.49) and 2019-20 (5.12). The significantly highest $\mathrm{H} / \mathrm{N}$ ratio was observed with PA 402 in the years of 2017-18 (4.38), 2018-19 (5.64) and 2019-20 (5.93). The times of sowing did not significantly influence plant height $(\mathrm{cm})$ in 2018-19 and 2019-20. The number of nodes per plant was not significant among genotypes in all three years of experimentation. However, between dates of sowing significant differences were observed in 2017-18 and 2018-19. Planting on 4 August observed significantly 


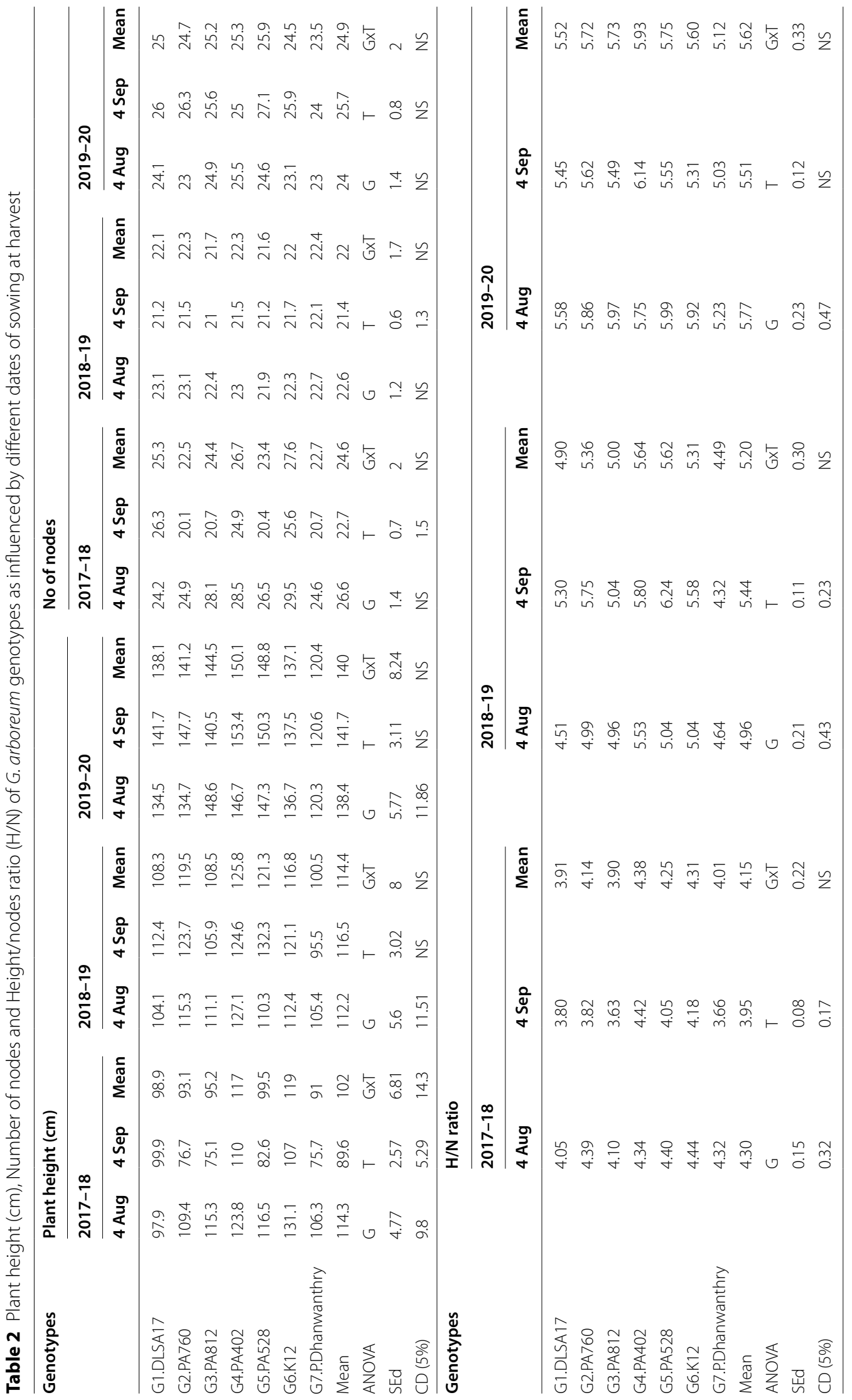




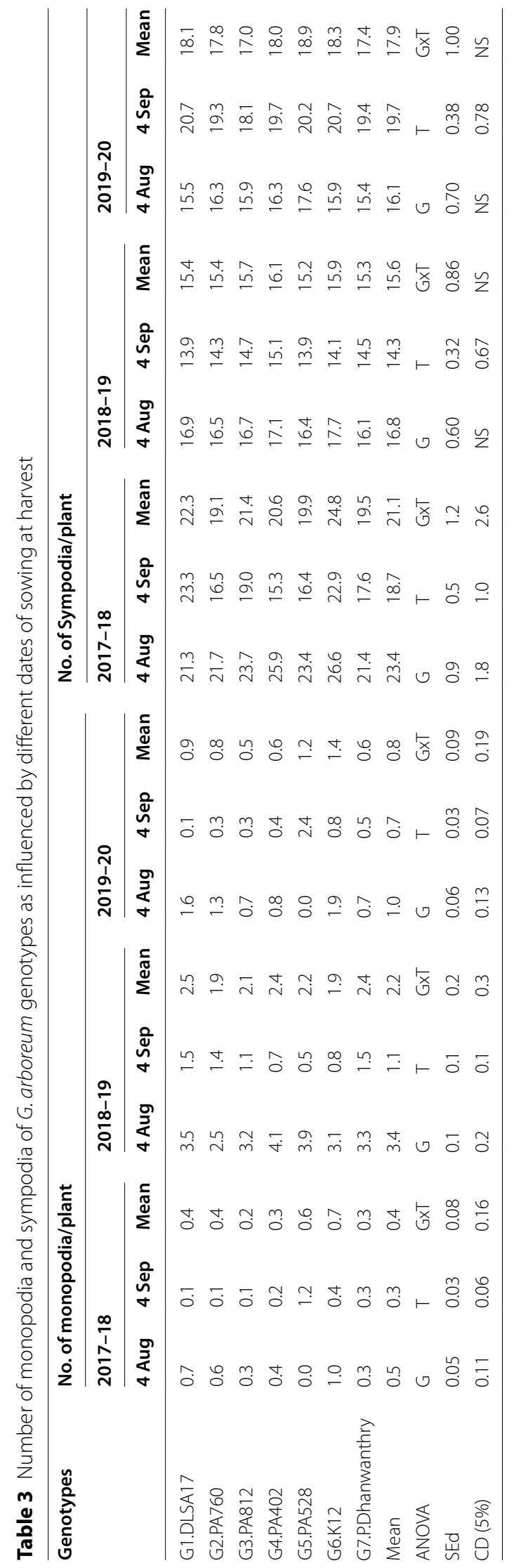


mean higher number of nodes with 16.6 and 22.7, respectively, at the two years of 2017-18 and 2018-19 (Table 2). The $\mathrm{H} / \mathrm{N}$ ratio was significantly differed between times of sowing and 4 August registered the highest of 4.32 and 4.64 in the years of 2017-18 and 2018-19, respectively. The result on number of monopodia per plant was found to be significantly influenced by genotypes and times of sowing. Amongst all genotypes, K-12 registered the significantly highest number of mean monopodia with value of 0.7 and 1.4 during 2017-18 and 2018-19 years, respectively (Table 3 ). The early sowing of G. arboreum on 4 August showed the significantly highest number of monopodia with value of $0.5,3.4$ and 0.7 , respectively, across years of 2017-18, 2018-19 and 2019-20. The similar result observed with number of sympodia per plant of 23.4, 16.8 and 16.1 which was significantly higher in 4 August sowing in respective with all three years 2017-18, 2018-19 and 2019-20 (Table 3). The Leaf Area Index (LAI) at 150 DAS was significantly influenced by genotypes and times of sowing factors. The significantly mean highest LAI of 3.5 with K 12 at 2017-18, 8.4 with Phule Dhanwanthry in 2018-19 and LAI of 3.0 with PA 528 in 2019-20 were found (Table 4). Between the times of sowing, 4 August registered the significantly highest LAI of 3.6 and 6.9 in 2017-18 and 2018-19, respectively. The results on dry matter production $(\mathrm{kg} / \mathrm{ha})$ revealed that the significantly highest of 4456, 4850 and $5156 \mathrm{~kg} /$ ha in 2017-18,2018-19 and 2019-20 recorded with K 12 , respectively, and which was followed by DLSA 17 in 2017-18 and 2019-20 and PA 402 in 2018-19 (Table 4).

\section{Yield attributes}

The results revealed that the genotypes and times of sowing significantly influenced number of bursted bolls and boll weight (g) traits. The significantly highest mean number of bursted bolls of 5.5 with K-12 in 2017-18, 6.7 with PA 528 in 2018-19 and 1.7 with Phule Dhanwanthry in 2019-20, respectively, were counted (Table 5). Planting of G. arboreum on 4 August significantly increased mean number of bursted bolls of 4.2, 9.5 and 1.9 in the years of 2017-18, 2018-19 and 2019-20, respectively. Planting of G. arboreum on 4 September recorded 26.2, 75.8 and $78.9 \%$ reduced bursted bolls per plant as compared to 4 August planting in 2017-18, 2018-19 and 2019-20, respectively.

In this study, it is observed that genotype, PA 402 (2.5 g), PA 760 (2.4 g) and Phule Dhanwanthry (2.5 g) exhibited significantly mean highest boll weight in 2017-18, 2018-19 and 2019-20, respectively (Table 4). Between times of sowing, 4 August planting registered significantly higher boll weight with value of $2.6,2.3$ and 2.5 in 2017-18, 2018-19 and 2019-20, respectively, which was 30.0, 15.0 and $19.0 \%$ higher than 4 September sowing of respective years.

\section{Seed cotton yield}

The first year (2017-18) results indicated that amongst the genotypes, K-12 registered the significantly highest seed cotton yield (1360 kg/ha) followed by Phule Dhanwanthry (1050 q/ha) and DLSA -17(929 q/ha). In 201920, the results revealed that PA 812 (490 kg/ha) showed significantly mean highest seed cotton yield (Table 7 and Fig. 1). However, genotypes were not varied significantly in the year of 2018-19. Significantly higher yield was recorded with 4 August sowing in 2017-18(1060 kg/ ha), 2018-19 (2451 kg/ha) and 2019-20 (528 kg/ha) than 4 September sowing in 2017-18 (800 kg/ha), 2018-19 (678 kg/ha) and 2019-20 (134 kg/ha), respectively.

The combined analysis of variance of years, genotype and different sowing dates in this study found that significant variation between years, interaction of year with times of sowing, interaction of year with genotypes and interaction of year with genotypes and times of sowing. The pooled analysis results found that the significantly highest mean seed cotton yield was recorded with Phule Dhanwanthry (1069 kg/ha) which was on par with $\mathrm{K} 12$ (1027 kg/ha), DLSA 17 (977 kg/ha) and PA 812 (951 kg/ ha) (Table 6). Planting at 4 August found that the significantly higher seed cotton yield (1345 kg/ha) in comparison with 4 September sowing (536 kg/ha). The interaction results in pooled data revealed that genotype PA 812 planted at 4 August sowing registered the significantly highest seed cotton yield (1487 kg/ha) which was on par with all genotypes sown on 4 August except PA 402.

\section{Nutrient uptake}

The data on nutrient uptake ( $\mathrm{kg} / \mathrm{ha}$ ) revealed that the significantly highest mean nitrogen of 111.7 and $104.6 \mathrm{~kg} /$ ha as well as phosphorus uptake of 21.13 and $22.3 \mathrm{~kg} / \mathrm{ha}$ were estimated with $\mathrm{K} 12$ in the years of 2017-18 and 2019-20, respectively, which was followed by DLSA17 with respect to nitrogen in the years of 2017-18 and 2019-20 (Tables 7 and 8). In the year of 2018-19, the significantly highest uptake of nitrogen $(157.9 \mathrm{~kg} / \mathrm{ha})$, phosphorus (30.9 kg/ha) and potassium $(134.8 \mathrm{~kg} / \mathrm{ha})$ was estimated with DLSA 17 which was followed by PA 528 with respect to all nutrients. The nutrient uptake $(\mathrm{kg} /$ ha) was significantly influenced by times of sowing and the significantly highest nitrogen uptake $(\mathrm{kg} / \mathrm{ha})$ of 83.2 , 157.5 and 78.9, phosphorus uptake (kg/ha) of 16.0, 30.3 and 18.3 as well as potassium uptake $(\mathrm{kg} / \mathrm{ha})$ of 74.5 , 133.7 and 81.1 were estimated with 4 August planting, respectively, in the years of 2017-18, 2018-19 and 201920 , respectively. 

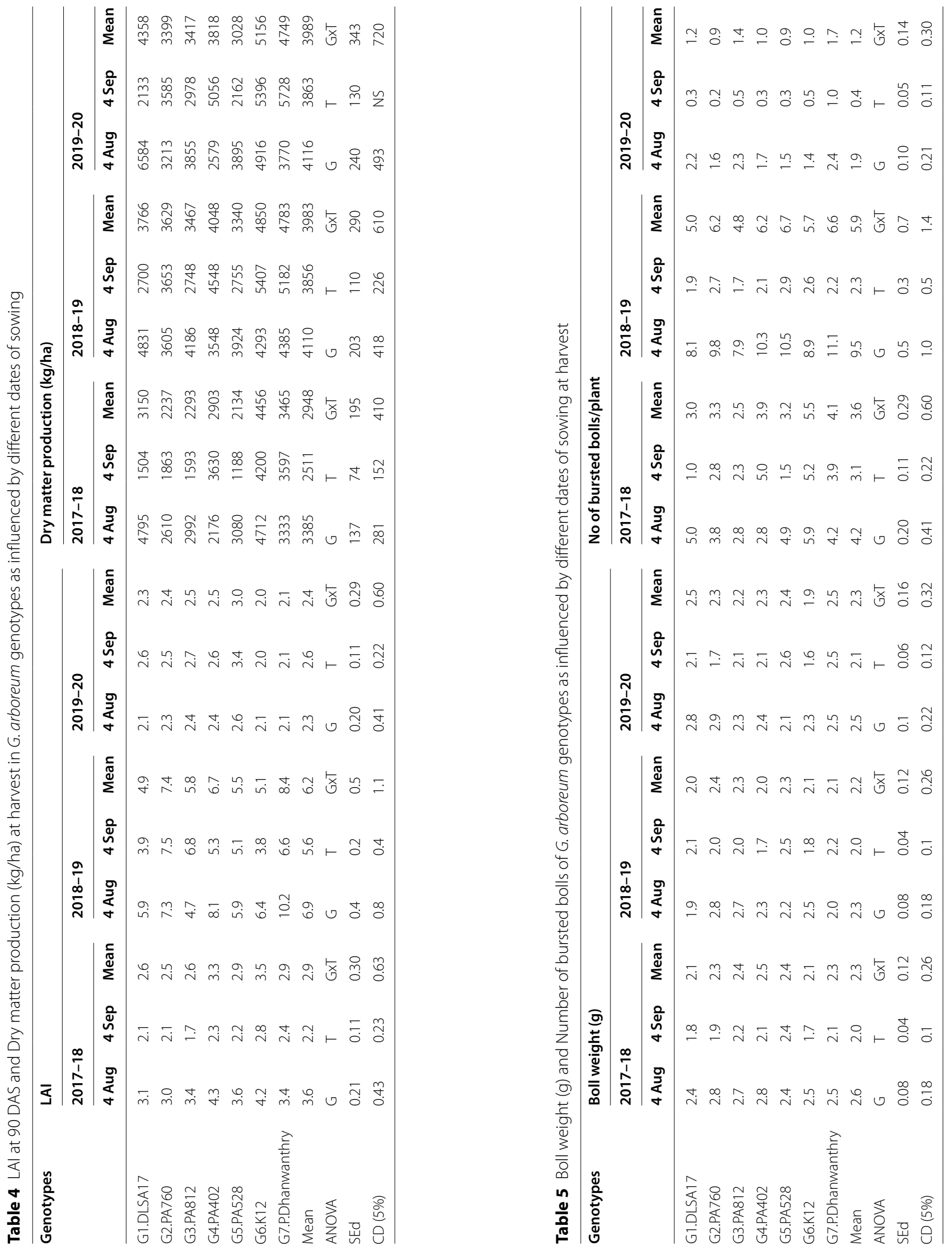


\section{Quality parameters}

The quality parameters analysis found that significantly least upper half length $(23.4 \mathrm{~mm})$, mean length $(17.9 \mathrm{~mm})$ and fibre strength $(21.8 \mathrm{~g} /$ tex $)$ but micronaire $(6.5 \mu /$ inch $)$ had maximum. Amongst long-linted G. arboreum genotypes tested, PA 760 recorded the significantly highest upper half length $(29.9 \mathrm{~mm})$, mean length $(24.9 \mathrm{~mm})$ and fibre strength (27.0 g/tex) which was on par with DLSA 17, PA 812 and PA 402 (Table 9). The highest fibre quality index of 349.7 was calculated with PA 760 followed by DLSA 17 (290.1), PA 812 (289.1) and PA 402 (276.9). The lowest FQI of 276.0 was calculated with Phule Dhanwanthry.

\section{Growth characters VS Seed cotton yield}

The values of correlation coefficients ( $r$ ) and their significance are presented in Table 10. The result on growth characters of G. arboreum genotypes planted in two different times of sowing was significantly correlated with seed cotton yield. Number of monopodial branches per plant are significant and positively correlated with seed cotton yield $(r=0.748)$. Plant height has negative and significantly contributed towards increase in the final seed cotton yield $(r=-0.334)$ and also exhibited negative association with number of bolls / plant. The positive significant correlation noticed with number of bursted bolls versus seed cotton yield $(r=0.975)$. The results further revealed that seed cotton yield was not significantly correlated with number of sympodia, number of nodes, $\mathrm{H} / \mathrm{N}$ ratio, boll weight and dry matter production traits.

\section{Yield model}

The regression fit of $\mathrm{Y}=-17,711.4+617.32$ Max. Temp. (46-90 DAS) +1.72SSH (90-120 DAS)-1.525RF (mm) (1-150 DAS) was developed by using three years mean seed cotton yield data of G. arboreum genotypes correlated with weather parameters $\left(\mathrm{r}^{2}\right.$ value of 0.806$)$. The predicted values are compared with actual data by Chisquare test and Chi-square values which indicated its non-significance (Table 10). Thus, mean that the equation could be used for prediction.

\section{Discussion}

\section{Growth characters}

Growth characters are varied amongst genotypes because of different genetic background and genotypes $\times$ year interaction. Amongst genotypes, the tallest plant was observed with K12 and PA 402 genotypes and shortest one was with Phule Dhanwanthry. The height to node ratio $(\mathrm{H} / \mathrm{N})$ was also shortest with Phule Dhanwanthry, and the highest one was observed with PA 402. The results interpreted that Phule Dhanwanthry is compact amongst all but PA 402 is non-compact and bushy type. The number of nodes per plant was not significantly differed with genotypes but number of monopodia and sympodia per plant, LAI and dry matter production were varied. Amongst genotypes, K-12 registered the significantly highest number of monopodia and sympodia per plant and dry matter production in many situations. Earlier, Bolonhezi et al. (2000) reported that varied growth characters attributed to their genetic makeup but the inconsistency among years indicated the strong environmental influence. Growth characters are varied amongst genotypes because of different genetic makeup (Hussain et al. (2007).

The times of sowing significantly influenced the number of nodes per plant, $\mathrm{H} / \mathrm{N}$ ratio, monopodia, sympodia, LAI and dry matter production. The planting on 4 August observed higher growth characters thus indicated that the specific periods received optimum weather condition for plant growth. Monopodial and sympodial branches in desi cotton were found to be significant for different sowing dates as presented by Jan et al. (2017).

\section{Yield attributes}

Yield is polygenic trait and does not controlled by single gene, but yield components are controlled by single gene (Chinchane et al. 2018). Thus, the yield is an end product of interaction between yield components and the environment. Seed cotton yield is the end of product of many factors, which singly and jointly influence it (Grafius 1959). The genotypes were varied with number of bursted bolls and boll weight (g). The variability of bursted bolls amongst genotypes was reported by Dhivya et al. (2014), Reddy and Sarma (2014) and Latif et al. (2015). Boll weight ( $\mathrm{g}$ ) is not up to the mark as compared to existing Bt hybrids under cultivation; however, maximum of $2.5 \mathrm{~g}$ was observed with high performing genotypes (PA 402, PA 760 and Phule Dhanwanthry). In G. arboreum (desi) cotton, boll weight is generally low as compared to hirsutum genotypes (Chinchane and Baig 2018).

Planting on 4 August observed higher number of bursted bolls and boll weight (g), and reduction of 26.2, 75.8 and $78.9 \%$ of bursted bolls was calculated with 4 September planting in 2017-18, 2018-19 and 2019-20, respectively, as compared to 4 August. The planting of 4 August observed 30.0, 15.0 and 19.0\% higher boll weight than 4 September sowing for the respective years of 2017-18, 2018-19 and 2019-20. Delayed planting usually reduces number of bursted bolls due to delayed physiological maturity and carbohydrate deficiency (Gwathmey and Clement 2010). Delaying of planting pushed cotton plants for unfavourable weather for crop growth thus consistently decrease number of opened bolls (Elayan et al. 2015). The weather data recorded from 46-120 DAS of growth stage of 4 August and 4 September planting 


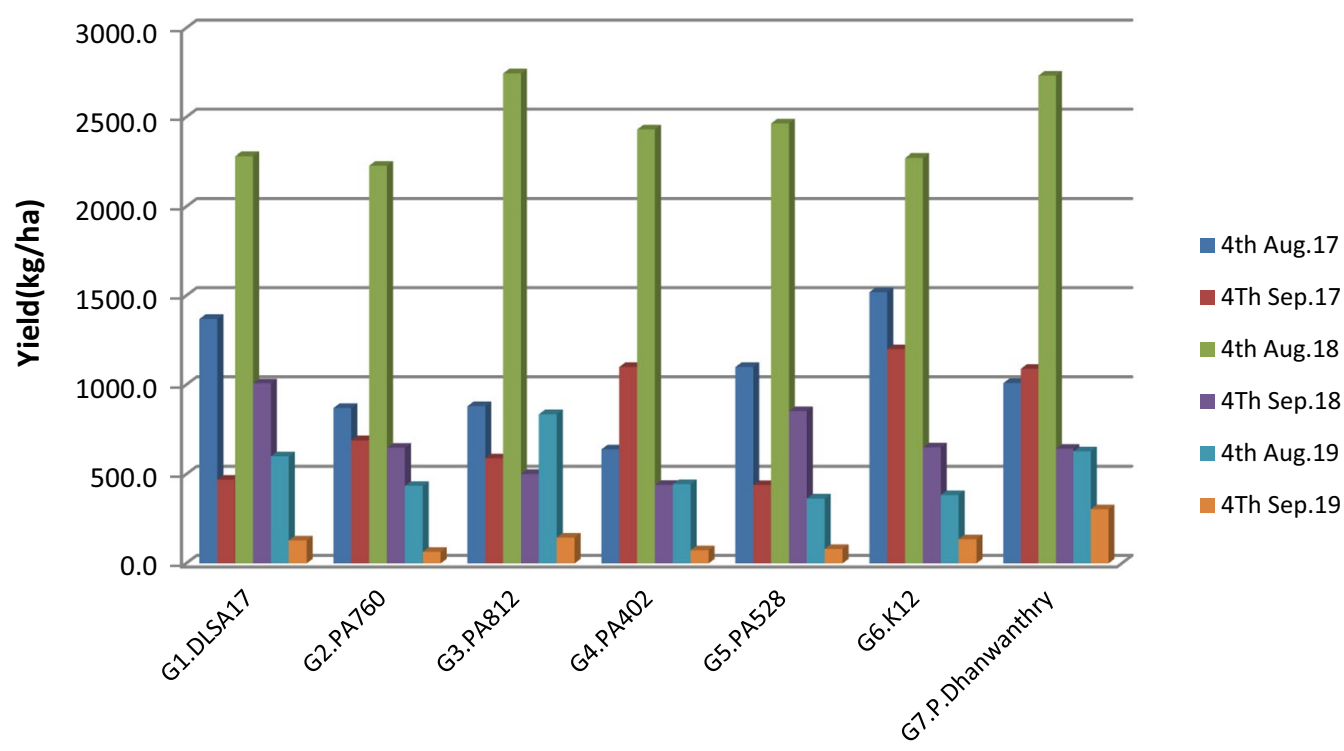

Fig. 1 Seed cotton yield ( $\mathrm{kg} / \mathrm{ha}$ ) by genotypes and times of sowing

indicated the maximum temperature $\left({ }^{\circ} \mathrm{C}\right)$ of 30.8 and 29.9, minimum temperature $\left({ }^{\circ} \mathrm{C}\right)$ of 22.4 and 21.6 and, SSH of 5.02 and 4.6, respectively. The climate variables reported in 4 August were more favourable for cotton production. Minimum temperature decreased in late sowing which does not favour proper boll maturation of seed cotton (Ali et al. 2004). Yeates et al. (2013) reported that cooler night temperature might be detrimental to boll retention and growth. Reduction in yield parameters in later sowing dates might be due to poor environmental conditions particularly minimum temperature falling at the time of reproductive stage (Manjeet et al. 2019). The gradual reduction in boll weight by late sowing was reported by Sankaranarayanan et al. (2020).

\section{Seed cotton yield}

The pooled analysis found that Phule Dhanwanthry, K-12, DLSA 17 and PA 812 are high performing genotypes. The genotypes had higher number of bursted bolls/plant which in turn registered higher seed cotton yield. Manivannan et al. (2018) reported that number of bolls/plant was the major contributor towards the seed cotton yield.

The effect of sowing time was consistent across genotypes and years of experimentation and higher yield was recorded with 4 August planting than 4 September. In 4 August planting, the prevalence of congenial weather conditions resulted an improved and balanced vegetative and reproductive growth thus ultimately resulted as higher seed cotton yield. The optimum time planted cotton had accumulated more of its resources and assimilates into higher reproductive growth. Presumably, the early planted cotton is able to take advantage of more favourable weather conditions than late planted cotton as observed by Pettigrew and Adamczyk (2006). Early sown crops had $32 \%$ more bursted bolls than the latesown crops due to easy access of available resources early in the season (Khan et al. 2017). Pettigrew (2002) also observed that the early planted cotton yielded $10 \%$ more lint than that produced by the late planted cotton. Ali et al. (2009) showed that the maximum seed cotton yield of $2039 \mathrm{~kg} \mathrm{ha}^{-1}$ was obtained with early sowing. The reproductive development in late sown crop was affected by cooler temperature and low light, which reduced photosynthetic activity and transport of carbohydrates to fruit structures (Gormus and Yucel 2002; Liu et al. 2015; Zhang et al. 2014). The lesser yield was due to sub-optimal weather conditions in late sowing date as reported by Gormus and Yucel (2002) and Sankaranarayanan et al (2020)

Amongst years of experimentation, 2018-19 resulted as higher performance of G. arboreum, despite the fact that the genotypes were repeated following similar management practices in all three years. The analysis of weather parameters found that seasonal rainfall received were 472.3, 396.8 and $686.6 \mathrm{~mm}$ during 2017-18, 201819 and 2019-20, respectively. G. arboreum is known for its suitability in low rainfall region and the less rainfall balanced the vegetative and reproductive growth and led to realization of higher yield. Venugopalan and Pundarikakshudu (1999) indicated that mono-cultured G. arboreum was superior to G. hirsutum in nine out of eleven years except in years experiencing heavy rainfall. 


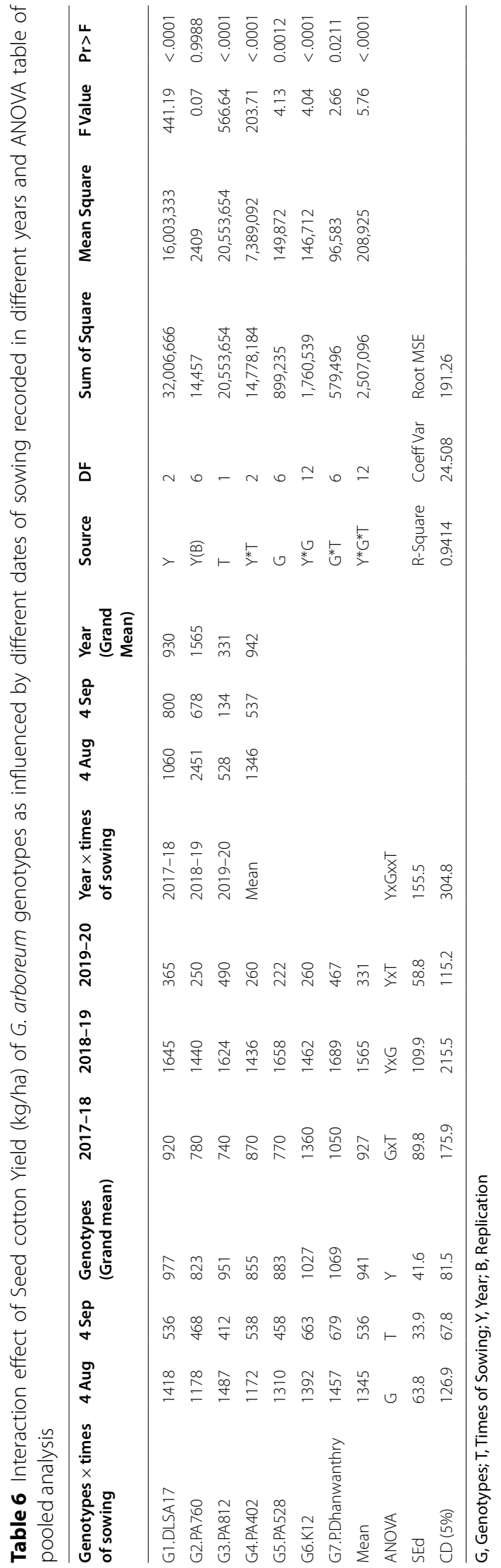



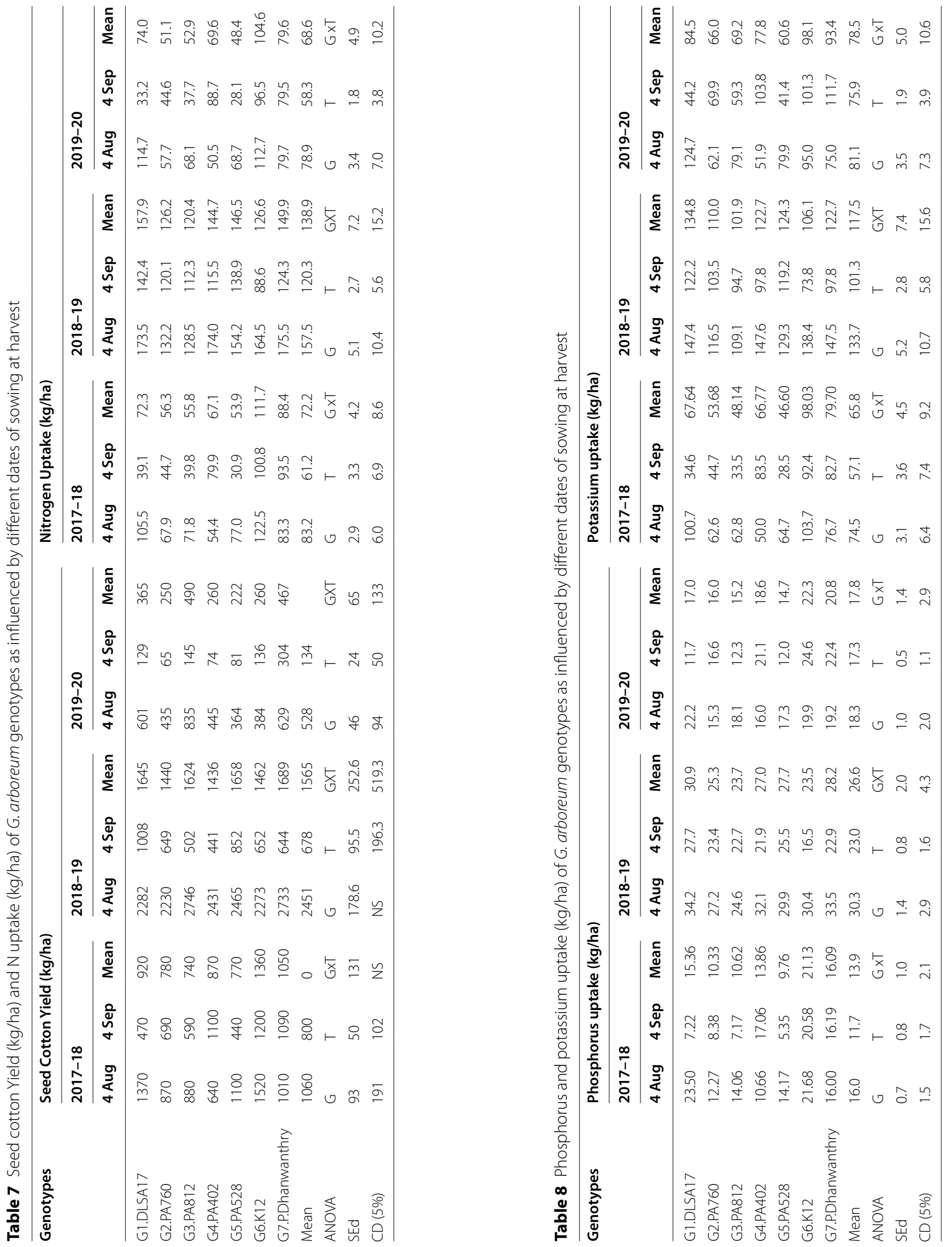
Thus, G. arboreum is better adapted to drier conditions. The high variation of seed cotton yield in different experimental years has been reported by many workers (Singh et al. 2012, Tuteja 2006 and Singh et al. 2014). Even though G. arboreum is our land races and existing in the local environment since so many years, because of high genotype $\times$ environment interaction, the species showed high variation in yield.

\section{Nutrient uptake}

The genotypes viz., K-12, DLSA 17 and PA 528 were estimated higher nutrient uptake of major nutrients in different years. The superior plant growth characteristics registered with the genotype might be attributed for the increased nutrient uptake. The boosted growth parameters enabled the increased uptake of nutrients (Sankaranarayanan and Nalayini 2015). Ramakal et al. (1988) reported that higher nutrient uptake might be due to genetic richness of that variety resulted in high dry matter production and uptake was a positive function of dry matter yield. The genotype, which uptake more nitrogen, naturally boosted the uptake of other nutrients including phosphorus and potassium (Nanjundappa et al. 1994). The major nutrients uptake ( $\mathrm{kg} / \mathrm{ha})$ was the highest with 4 August planting. The conducive climate prevailed in 4 August planting resulted higher growth characters and dry matter production and ultimately resulted in higher nutrient uptake.

\section{Quality parameters}

The genotypes are varying with respect to quality parameters because of different genetic background. Phule Dhanwanthry is not grouped under long-linted $G$. arboreum, which registered less quality parameters and fibre quality index. Amongst long-linted G. arboreum genotypes tested, PA 760 recorded higher quality parameters and fibre quality index. The results of better performance of PA 760 are in agreement with the reports of Deshpande et al. (2003), Sakhare et al. (2005), Bolek et al. (2010) and Patil et al. (2015). Planting times had not influenced quality parameters significantly. The similar result was reported by Sankaranarayanan et al. (2011).

\section{Growth characters VS Seed cotton yield}

Studying the relationship between growth and yield characters versus seed cotton yield is necessary which will facilitate to select better varieties with desirable characteristics by Chinchane et al. (2018). Number of monopodial branches per plant $(r=0.748)$ and number of bursted bolls $(r=0.975)$. were significantly and positively correlated with seed cotton yield. Jan et al. (2017) reported that monopodia and seed cotton yield were significantly and positively correlated with each other. Phenotypic and genotypic association of number of monopodial branches and seed cotton yield reported by Ahuja et al. (2016) and Alkuddsi et al. (2013). However, the findings observed by the author in present research work are not in agreement to the results found by Killi (1995). This may be due to different genetic makeup of the experimental materials. The positive correlation of bursted bolls and seed cotton yield was reported by Ahuja et al. (2016), Salahuddin et al. (2010) and Yehia and El-Hashash (2019).

Plant height has significant negative correlation with number of bursted bolls and seed cotton yield. G. arboreum is known for putting rank vegetative growth, higher plant height with lesser yield attributes and seed cotton yield under high (more than optimum) rainfall situation. The productivity of different species of cotton under rainfed condition, high rainfall year normally favours G. hirsutum over G. arboreum/G. herbaceum and the reverse is true for a low or scanty rainfall year as reported by Sankaranarayanan et al.(2010).

The growth characters include number of sympodia, number of nodes, $\mathrm{H} / \mathrm{N}$ ratio, boll weight and dry matter production that were not influenced the seed cotton yield significantly. These results are in agreement with those of Afiah and Ghoneim (2000) as they found a very low direct effect of sympodia on seed cotton yield. G. arboreum due to its negative association with high rainfall (more than optimum) thus leads to uncontrollable vegetative growth resulted in higher dry matter production with less reproductive growth. Cotton often produces more vegetative growth than is needed for maximum boll production and yield especially when climatic conditions favour vegetative growth (Nawalkar et al.2015).

\section{Yield model}

Plant growths mostly rely on environmental factors, management practices and genotypes characteristics. Weather is the foremost feature of crop growth and yield (Manjunatha et al.2010). The yield model based on regression was developed $(\mathrm{Y}=-17,711.4+617.32$ Max. Temp. (46-90 DAS) +1.72SSH (90-120 DAS)-1.525RF $(\mathrm{mm})(1-150 \mathrm{DAS}))$ and validated $\left(\mathrm{r}^{2}\right.$ value of 0.806$)$. The cotton crop is cultivated during winter season (AugustFeb) in that experimental zone. The higher contribution of maximum temperature is reported in the equation (coefficient of 617.32). The mean maximum temperatures $\left({ }^{0} \mathrm{C}\right)$ recorded during cropping periods were ranged from 29.1 to 32.2 at critical period of 46-90 DAS which was less than optimum required for cotton growth; hence, recorded maximum temperature was positively and linearly contributed for yield. Mauney (1986) stated that all processes leading to square, blossom and boll initiation and maturation are temperature-dependent. Manjeet et al. (2019) reported that documented that sub-optimum 

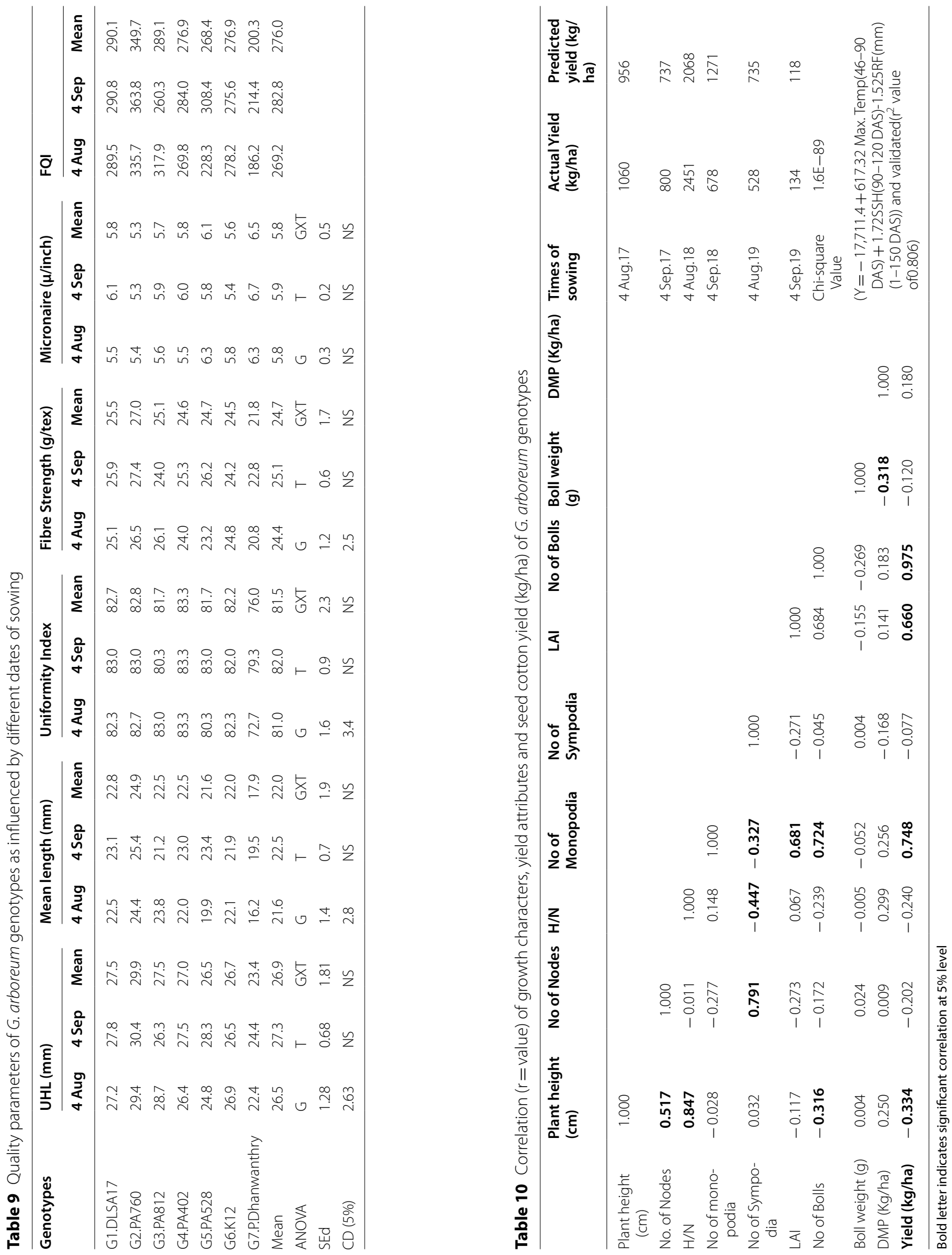
temperatures retarded growth and fibre development. Seed cotton yield per plant was greatly influenced by climatic factors, especially temperature in various cultivation times (Jan et al. (2017) and Ali et al. (2003). The positive coefficient (1.7238) of sun shine hours (90120DAS) is reported in the equation. The sunshine hours reported in the range of 4.6 to 9.5 recorded during the different years of crop growth periods of 90-120 DAS; the variation in SSH influence seed cotton yield positively and significantly. Plants with the higher boll load are the most sensitive to low light intensity due to their increased requirements of photosynthate (Guinn 1998). The lint yield reduction resulting from low light situations is primarily due to fewer bolls being produced on the plants (Pettigrew 1994). High rainfall had negative contribution as reported in the equation (coefficient of -1.525), and the similar result was reported by Venugopalan and Pundarikakshudu (1999). Balasubramaniyan (1987) found that G. arboreum cotton produced excess vegetative growth with less seed cotton yield (40\% less) as compared to G. hirsutum when excess rainfall $(692 \mathrm{~mm})$ was received at early stage of crop growth (48\%) as compared to deficit rainfall year $(363 \mathrm{~mm})$ with $33 \%$ at early growth stage. Rainfall and temperatures are effective variables for G. hirsutum cotton, while it is rainfall alone for G. arboreum cotton (Mangat 1985). The study indicated that less rainfall, optimum temperature and sunshine hours have positive influence on G. arboreum.

\section{Conclusions}

The results concluded that the significantly highest mean seed cotton yield was recorded with Phule Dhanwanthry (1069 kg/ha) which was on par with K12 (1027 kg/ha), DLSA 17 (977 kg/ha) and PA 812 (951 kg/ha). Planting at 4 August found that the significantly higher seed cotton yield $(1345 \mathrm{~kg} / \mathrm{ha})$ in comparison with 4 September sowing (536 kg/ha). Amongst long-linted genotypes, PA 760 recorded the significantly higher fibre quality index (349.7).

\begin{abstract}
Abbreviations
HVI: High Volume Instrument; DTPA: Diethylene Triamine Penta Acetic acid; EC: Electrical conductivity; RH: Relative humidity; CD: Critical Difference; SSH: Sun Shine Hours; N: Nitrogen; P: Phosphorus; K: Potassium; dSm ${ }^{-1}$ : DesiSiemens per meter; LAl: Leaf Area Index; Y: Yield; FQI: Fibre Quality index; H/N ratio: Height to node ratio; DAS: Days after Sowing; SEd: Standard error of difference.
\end{abstract}

\section{Acknowledgements}

The authors duly acknowledge the facilities and support provided by The Director, Central Institute for Cotton Research, Nagpur, 440 010, Maharashtra, India.

\section{Authors' contributions}

$\mathrm{KSN}$ - first author, involved in planning, execution of field experiments, data collection on biometric, analysis of quality parameters, reporting the data and article preparation; MVG — second author, involved in interpretation of results.
KNJ - third author, involved in analysis on nutrients in plants. All the author read and approved for final manuscript.

Funding

Institute grant.

Availability of data and materials

Weather data of experimental periods and data of different experimental years are available with us.

\section{Declarations}

\section{Ethical approval and consent to participate}

The project is aimed to find out performance of $G$. arboreum genotypes with sowing window. The experiment does not involve any component related to ethical and animal welfare issues. The bio-safety is not applicable here.

\section{Consent for publication}

Not Applicable.

\section{Competing interests}

The authors declare that they have no competing interests.

\section{Author details}

${ }^{1}$ ICAR-Central Institute for Cotton Research, Regional Station, Coimbatore, Tamil Nadu 641003, India. ${ }^{2}$ ICAR-Central Institute for Cotton Research, Nagpur, Maharashtra, India.

Received: 23 April 2021 Accepted: 1 June 2021

Published online: 08 June 2021

\section{References}

Afiah SAN, Ghoneim EM (2000) Correlation, stepwise and path co-efficient analysis in Egyptian cotton under saline conditions. Arab Univ Agric Sci 8(2):607-618

Ahuja SL, Monga D, Meena RA, Kumar R, Saxena N (2016) Effect of intra row spacings on estimates of phenotypic and genotypic correlation coefficients in cotton (Gossypium arboretum L.). Indian J Agric Sci 86(2):173-177

Ali L, Ali M, Mohy-Ud-Din Q (2003) Assessment of optimum nitrogen requirement and economics of cotton (Gossipium hirsutum L.) crop for seed yield. Int J Agric Biol 5(4):493-495

Ali MS, Mohy-ud-din Q, Ali MA, Shahzadsabir AL (2004) Cotton Yield as Influenced by different sowing dates under the climatic conditions of Vehari-Pakistan. Int J Agric Biol 6(4):644-646

Ali MA, Abbas A, Muhammad Y, Khan TM, Hassan HM (2009) Genetic basis of some quantitative traits in upland cotton (Gossypium hirsutm L.). Plant Omics 2(2):91-97

Alkuddsi Y, Patil SS, Manjula SM, Patil BC, Nadaf HL, Nandihali BS (2013) Association analysis of seed cotton yield components and physiological parameters in derived F1 inter specific crosses of cotton. Bioscience Methods 4(5):23-33

Balasubramaniyan TN (1987) Performance of G. arboreum and G. hirsutum cotton under intercropping (black gram) and land management practices. Ph.D. thesis Tamil Nadu Agricultural University, Coimbatore, India

Blaise D, Kranthi KR, Ravindran CD, Thalal K (2020) High plant density can improve the productivity of rainfed Asiatic cotton (Gossypium arboreum L.). Arch Agron Soil Sci. https://doi.org/10.1080/03650340.2020.1741553

Bolek Y, Cokkizgin H, Bardak A (2010) Combining ability and heterosis for fibre quality traits in cotton. Plant Breed Seed Sci 62:3-16

Bolonhezi AC, Justi MM, Oliveira RC, Bolonhezi C (2000) Narrow spacing for varieties of herbaceous cotton (Gossypium hirsutum L.) plant development and retention of reproductive structures. Field Crop Res 53(5):611-613

Brink M (2011). Gossypium arboreum L. Record from PROTA4U. In: Brink M, Achigan-Dako EG (eds) PROTA (Plant Resources of Tropical Africa/Ressources <http://www.prota4u.org/search.asp>. 
Chinchane VN, Baig KS (2018) Performance of long linted desi cotton (Gossypium arboreum $\mathrm{L}$.) genotypes for yield and fibre quality parameters under rainfed condition. J Pharmacognosy Phytochem 7(5):3409-3411

Chinchane VN, Deosarkar DB, Kalpande HV (2018) Stability analysis for seed cotton yield and its component traits in hybrids of desi cotton (Gossypium arboreum L.). Int J Curr Microbiol Appl Sci 7(9):1000-1012. https://doi.org/10. 20546/ijcmas.2018.709.119

Deshpande LA, Baig KS, Nagare VP (2003) Combining ability studies for yield, fibre quality and morphological traits in desi cotton (Gossypium arboreum L.). J Maharashtra Agric Univ 28(1):36-39

Dhivya R, Amalabalu P, Pushpa R, Kavithamani D (2014) Variability, heritability and genetic advance in upland cotton (Gossypium hirsutum L.). Afr J Plant Sci $8(1): 1-5$

Elayan ED, Sohair AAMA, Abdel-Gawad NSD, Wageda AEF (2015) Effect of delaying planting date on yield, fibre and yarn quality properties in some cultivars and promising crosses of Egyptian cotton. Am-Eurasian J Agric Environ Sci 15(5):754-763

Gormus O, Yucel C (2002) Different planting date and potassium fertility effects on cotton yield and fiber properties in the Cukurova region, Turkey. Field Crops Res 78(2-3):141-149

Grafius JE (1959) Heterosis in Barley. Agron J 51:551-554

Guinn, G (1998) Causes of square and boll shedding. Proceedings of the Beltwide Cotton Conference, National Cotton Council, Memphis, TN 2:1355-1364

Gwathmey CO, Clement JD (2010) Alteration of cotton source-sink relations with plant population density and mepiquat chloride. Field Crop Res 116(1-2):101-107

Hussain M, Ahmad A, Zamir S (2007) Evaluation of agro-qualitative characters of five cotton cultivars (Gossypium hirsutum L.) grown under different conditions. Pak J Agric Sci 44(4):575-580

Iqbal M, Khan MA, Chattha WS, Abdullah K, Majeed A (2019) Comparative evaluation of Gossypium arboreum L. and Gossypium hirsutum L. genotypes for drought tolerance. Plant Genetic Resources 18(5):351-358. https://doi.org/ 10.1017/S1479262120000374

Jan K, Waseem M, Baloch DM, Baloch AH, Khan MA, Khan T, Rashid M, Ali Q (2017) Morphological lodge of desi cotton (Gossypium arboreum L.) genotypes and stage-manage by planting under dry tropical prospect. J Agric Sci 2(28):106-112

Khan A, Ullah N, Wang L, Tan DKY, Yang G, Munsif F, Ali S, Hafeez A (2017) Planting density and sowing date strongly influence growth and lint yield of cotton crops. Field Crop Res 209:129-135

Killi F (1995) Path coefficient analysis and correlations for cotton (Gossypium hirsutum L.) yield and some yield components in the East Mediterranean and GAP (South eastern Anatolian Project) regions. Turkish J Agric for 19(5):379-382

Kranti KR (2015) Desi cotton—returns? Cotton Stat News 15:1-4

Latif A, Bilal M, Hussain SB, Ahmad F (2015) Estimation of genetic divergence, association, direct and indirect effects of yield with other attributes in cotton (Gossypium hirsutum L.) using biplot correlation and path coefficient analysis. Int J Trop Plant Res 2(2):120-126

Liu J, Meng Y, Chen J, Lv F, Ma Y, Chen B, Wang Y, Zhou Z, Oosterhuis DM (2015) Effect of late planting and shading on cotton yield and fibre quality formation. Field Crop Res 183:1-13

Mangat NS (1985) Impact of weather and technology on cotton production in Punjab. Indian J Agric Sci 55:328-352

Manivannan A, Punit Mohan M, Saravanan R, Waghmare VN (2018) Morphological characterization of asiatic cotton (G. arboretum L.) germplasm of India. Electronic J Plant Breed 9(2):673-681. https://doi.org/10.5958/0975-928X. 2018.00081 .9

Manjeet, Anurag, Ram Niwas, Khichar ML, Anil Kumar, Rahul (2019) Climate change impact on cotton crop in Haryana, India. Bull Environ Pharmacol Life Sci 8(2):552-554

Manjunatha MJ, Shalephyati AS, Koppalkar BG, Pujari BT (2010) Yield and yield components, uptake of nutrients, quality parameter and ecomonics of Bt cotton (Gossypium hirsutum L.) Genotypes as influenced by different plant densities. Karnataka J Agric Sci 23:423-425

Mauney JR (1986) Vegetative growth and development of fruiting sites. In: Mauney JR, Stewart JM (eds) Cotton physiology. The Cotton Foundation, Memphis, Tenn, pp. 11-28

Nanjundappa G, Manure GR, Badiger MK (1994) Yield and uptake of fodder Maize (Zea mays) as influenced by nitrogen, phosphorus and potassium. Indian J Agron 39(3):473-475
Narayanan SS, Parchuri Vidyasagar, Srinivasu Babu K (2014) Cotton Germplasm in India -New Trends; In: World Cotton Germplasm Resources Edited by Ibrokhim Abdurakhmonov, pp 87-118

Nawalkar DP, Ban YG, Mote BM, KumarV (2015) Influence of growth regulators on thermal energy requirement at various phenophases in transgenic cotton. J Agrometeorol 17(2):254-256

Patil SS, Magar NM, Sonawane HS, Shinde PY, Pawar VY (2015) Heterosis and combining ability for seed cotton yield and its component traits of diploid cotton (Gossypium arboreum L.). J Cotton Res Dev 29(1):23-25

Pettigrew WT (1994) Source-to-sink manipulation effects on cotton lint yield and yield components. Agron J 86:731-735

Pettigrew WT (2002) Improved yield potential with an early planting cotton production system. Agron J 94(5):997-1003

Pettigrew WT, Adamczyk JJ (2006) Nitrogen fertility and planting date effects on lint yield and Cry1 Ac (Bt) endotoxin production. Agron J 98:691-697

Ramakal KS, Khera AP, Bhatia RM, Gupta SP, Duhan BS (1988) Effect of combined application of FYM and inorganic fertilizer on grain yield and soil fertility status in Bajra -wheat crop sequence. Haryana J Agron 4(1):42-47

Reddy YR, Sarma ASR (2014) Genetic variability for yield components and fibre characters in cotton (Gossypium arboreum L.). Plant Arch 14(1):417-419

Sakhare BA, Wandhare MR, Ladole MY, Wakode MM (2005) Combining ability studies in diploid cotton. J Cotton Res Dev 19(1):52-54

Salahuddin S, Abro S, Rehman A, lqbal K (2010) Correlation analysis of seed cotton yield with some quantitative traits in upland cotton (Gossypium hirsutum L.). Pak J Bot 42(6):3799-3805

Sankaranarayanan K, Nalayini P (2015) Performance and behavior of Bt cotton hybrids under sub-optimal rainfall situation. Arch Agron Soil Sci 61(8):1179-1197

Sankaranarayanan K, Praharaj CS, Nalayini P, Bandyopadhyay KK, Gopalakrishnan N (2010) Climate change and its impact on cotton. Indian J Agric Sci 80(7):561-575

Sankaranarayanan K, Praharaj CS, Nalayini P, Gopalakrishnan N (2011) Evaluation of $\mathrm{Bt}$ and non-Bt cotton hybrids under varied planting time. Indian J Agric Sci 56(1):68-73

Sankaranarayanan K, Prakash AH, Rajendran K (2020) Effect of sowing time on productivity of $\mathrm{Bt}$ and non Bt cotton under climate change. Bull Natl Res Centre. https://doi.org/10.1186/s42269-020-00400-144:146

Singh T, Sohu RS, Singh P, Rathore P, Sekhon PS, Buttar GS, Hassan H, Singh G (2012) Stability analysis of Bt transgenic cotton hybrids of Gossypium hirsutum L. for lint yield and fibre quality traits. J Cotton Res Dev 26(2):163-166

Singh S, Singh W, Choudhary AD (2014) Genotype x environment interaction and yield stability analysis in multi environment. Trop Subtrop Agroecosyst 17(2014):477-482

Snedecor WG, Cochran WG (1980) Statistical methods. lowa State University Press, Ames

Tuteja OP (2006) Comparative studies on stability parameters and sustainability index for selecting stable genotypes in upland cotton (Gossypium hirsutum L.). J Genet Breed 66(3):221-224

Venugopalan MV, Pundarikakshudu R (1999) Long-term effect of nutrient management and cropping system on cotton yield and soil fertility in rainfed vertisols. Nutr Cycl Agroecosyst 55:159-164

Venugopalan MV, Kranthi KR, Lakade S, Tandulkar NR (2016) Development of agro-technology to increase yields of a shy-bearer desi cotton species Gossypium arboreum race cernuumin a non-traditional area of cultivation. Curr Sci 110(4):692-695

Yeates SJ, Khal MF, Dougall AJ (2013) The impact of variable, cold minimum temperatures on boll retention, boll growth and yield recovery of cotton. J Cotton Sci 17:89-101

Yehia WMB, El-Hashash EF (2019) Combining ability effects and heterosis estimates through line $x$ tester analysis for yield, yield components and fiber traits in Egyptian cotton. Elixir Agric 131:53238-53246

Zhang D, Zhang L, Liu J, Han S, Wang Q, Evers JB, Li L (2014) Plant density affects light interception and yield in cotton grown as companion crop in young jujube plantations. Field Crop Res 169:132-139

\section{Publisher's Note}

Springer Nature remains neutral with regard to jurisdictional claims in published maps and institutional affiliations. 